\title{
FORMULASI STRATEGI DARI EVALUASI SIKLUS HIDUP PRODUK, STRATEGI KEKUATAN KOMPETISI DAN ANTICIPATING COMPETITOR'S ACTION STUDI KASUS CONVENIENCE STORE
}

\author{
Ratna Suminar. S \\ Program Studi Teknik Industri, Fakultas Teknik, Universitas Bhayangkara Jakarta Raya, \\ Jalan Harsono RM Nomor 67, Ragunan, Pasar Minggu, Jakarta Selatan, \\ ratna.suminar@dsn.ubharajaya.ac.id
}

\begin{abstract}
Abstrak
Penulisan ini merupakan evaluasi terhadap strategi keunggulan kompetisi dari studi kasus convenience store yang sempat menjadi pemimpin pasar di Indonesia. Dasar pemilihan convenience store ini untuk dijadikan studi kasus merujuk pada fenomena model bisnis di Indonesia ketika masuk pasar dan sangat mudah diterima oleh konsumen namun kemampuan bertahan di pasar tidak lama. Selama 9 tahun berada di pasar, produk ini akhirnya kalah oleh produk pengikut. Sehingga diperlukan evaluasi setiap tahap siklus hidup produk tersebut. Evaluasi menggunakan data sekunder dari literatur, melakukan pengamatan di beberapa negara seperti Singapur, Korea dan Jepang, serta melakukan studi literatur tentang competitive strategy, product life cycle. Hasil evaluasi terhadap product life cycle SE antara lain pada tahap perkenalan produk dibutuhkan selama 1 tahun, tahap pertumbuhan selama 2 tahun, tahap kemapanan selama 3 tahun dan tahap penurunan produk hingga dinyatakan tutup selama 3 tahun. Teknik analisis hasil evaluasi dengan menggunakan metode proses Anticipating Competitor's Actions. Hasil analisis yang diperoleh berupa rekomendasi strategi-strategi umum setiap tahap pada product life cycle yang dapat digunakan untuk produk perintis lainnya.
\end{abstract}

Keywords: Case Study Evaluation, Product Life Cycle, Competitive Advantage Strategy, Anticipating Competitor's Actions

\section{PENDAHULUAN}

Pada era revolusi industri 4.0, persaingan produk baik dalam bentuk barang maupun jasa semakin kuat. Kebebasan produk lokal maupun asing masuk dan keluar di pasar Indonesia semakin banyak. Perusahaan mempersiapkan produknya masuk ke pasar menjadi produk perintis dan pemimpin pasar (market leader) atau menjadikan produknya sebagai produk pengikut. Keduanya mempunyai peluang untuk berhasil dalam bersaing. Produk perintis dan menjadi pemimpin pasar dapat kalah bersaing dengan produk pengikutnya (follower). Sebagaimana yang diartikan oleh Kotler: 1997, bahwa produk merupakan jenis barang yang dapat dipasarkan dan dikonsumsi sesuai kebutuhan konsumen dengan memperhatikan kualitas, kemasan, atribut produknya. Berdasarkan rujukan tersebut maka setiap produk dipersiapkan untuk memiliki kemampuan bertahan selama mungkin di dalam pasar dengan mempersiapkan Competitive Advantage Strategy (CAS), termasuk menempatkan produknya pada segmen dan pangsa pasar yang dituju. Faktor-faktor pendukung perusahaan melakukan penawaran produk atas permintaan dari konsumen adalah jumlah penduduk, cita rasa dari konsumen yang memiliki kebutuhan serta keinginan yang berbeda-beda (Sukirno; 2016). Hal ini menjadi peluang bagi perusahaan untuk menetapkan CAS tersebut. Setiap produk mengalami Product Life Cycle (PLC), maka CAS disusun agar memberikan kemampuan produk untuk bertahan berada di pasar sampai dengan batas waktu mengalami penurunan. Banyak ditemukan PLC dari produk-produk asing bertahan dalam waktu tertentu namun dapat dikalahkan dengan produk pengikut terutama produk lokal dengan kualitas di bawah bahkan hampir menyerupai dari produk aslinya. Fenomena ini sampai saat ini masih ditemukan di pasar Indonesia. Pada saat produk masuk dengan mudah diterima oleh konsumen dan mendapatkan loyalitas dari konsumen. Evoria keinginan konsumen terhadap produk baru sangat besar, namun sangat sering ketika produk telah 
diterima dan dipercaya terjadi proses pembelajaran oleh perusahaan pesaing untuk mulai menduplikasi produk baru tersebut. Fenomena yang terus berulang terjadi pada setiap model bisnis produk luar Indonesia, untuk itu setiap produk memiliki CAS dan PLC dalam menghadapi pesaing terutama pengikut pasar. Salah satu model bisnis yang dijadikan studi kasus untuk menggabarkan pentingnya CAS yang dapat mempengaruhi PLC dari produk adalah convenience store berinisial SE. Convenience store bukan merupakan hal yang pertama di Indonesia, ada beberapa brand yang sudah lebih dahulu ada di Indonesia. Convenience store juga menyerupai warung dan mini market yang menyediakan kebutuhan sehari-hari dan sesaat. Konsep model bisnis retail/convenience store SE menyediakan produk-produk yang dirujuk berupa barang dan pelayanan (service). Convenience store SE sebagai studi kasus karena merubah prilaku konsumen (budaya) kota Jakarta, memperoleh keuntungan yang tinggi, pangsa pasar yang besar, cukup sukses di awal yang telah mengikuti perkembangan teknologi dan perubahan pasar, namun memiliki waktu yang cukup singkat untuk bertahan di pasar. Kilas balik peristiwa yang terjadi pada SE dikarenakan model bisnis ini menyediakan convenience goods yang sering dibutuhkan segera oleh konsumen dan memberikan pelayanan-pelayanan yang mudah kepada konsumen. Kemampuan SE dikarenakan memiliki competitive advantages strategies, seperti: 1) perusahaan membangun positive brand image terlebih dalam upaya menjadikan produk perintis pada pasar yang dituju, 2) mengurangi total biaya dengan memanfaatkan teknologi, alur penawaran dan distribusi yang efektif, 3) membangun loyalitas dari konsumen.

Evaluasi terhadap studi kasus SE dirumuskan dalam PLC SE, dan strategi antisipasi SE terhadap kompetitor maka selanjutnya diperoleh strategistrategi umum yang dapat direkomendasikan kepada model bisnis lainnya yang memperkenal produk baru terutama brand dari luar agar mampu bertahan lebih lama menghadapi produk pesaing terutama pengikut pasar yang banyak ditemukan di pasar Indonesia. Pengumpulan data secara deskriptif kualitatif dan penulisan ini fokus dengan menggunakan pengolahan dengan metode literasi dari teori PLC, CAS dan proses antisipasi terhadap aksi kompetitor. Hasil akhir dari penulisan ini adalah memberikan rekomendasi strategi kepada produk-produk perintis baru yang mendapat respon positif dari konsumen agar PLC dapat lebih lama bertahan terutama dalam menghadapi pengikut pasar. Kronologis keberadaan SE selama 9 tahun di Indonesia sebagai berikut:

Tabel 1.1

Kronologis Keberadaan Convenience Store SE

\begin{tabular}{|c|c|c|}
\hline Thn & Peristiwa & Detil Peristiwa \\
\hline 2008 & $\begin{array}{l}\text { Penandatanganan } \\
\text { Letter of Intent Master } \\
\text { Franchise SE }\end{array}$ & $\begin{array}{l}\text { Di Dallas-Amerika } \\
\text { Serikat }\end{array}$ \\
\hline 2009 & $\begin{array}{l}\text { 1. Penandatanganan } \\
\text { Master Franchise } \\
\text { Agreement. } \\
\text { 2. Pembukaan gerai } \\
\text { pertama di } \\
\text { Indonesia }\end{array}$ & $\begin{array}{l}\text { 1. Di Tokyo-Jepang } \\
\text { PT Modern } \\
\text { Internasional Tbk } \\
\text { (MDRN) } \\
\text { menyatakan, } \\
\text { sudah membayar } \\
\text { sebesar USD1,5 } \\
\text { juta untuk } \\
\text { membeli lisensi } \\
\text { SE untuk jangka } \\
\text { waktu } 20 \text { tahun } \\
\text { hingga } 2029 . \\
\text { Indonesia adalah } \\
\text { negara ke-17 di } \\
\text { dunia yang } \\
\text { membuka bisnis } \\
\text { waralaba SE } \\
\text { 2. Di Bulungan } \\
\text { Jakarta Selatan } \\
\end{array}$ \\
\hline 2010 & $\begin{array}{l}\text { 1. Gerai ke } 21 \\
\text { 2. Pembangunan } \\
\text { infrastruktur } \\
\text { pendukung untuk } \\
\text { penyediaan fresh } \\
\text { food. }\end{array}$ & $\begin{array}{l}\text { Pembangunan } \\
\text { combine distribution } \\
\text { center yang terdiri } \\
\text { dari central kitchen, } \\
\text { central warehouse, } \\
\text { training centre. }\end{array}$ \\
\hline 2011 & 57 gerai & $\begin{array}{l}\text { Pembukaan Pabrik } \\
\text { makanan } \\
\text { Commissary \& } \\
\text { Bakery }\end{array}$ \\
\hline 2012 & 100 gerai & \\
\hline 2014 & $\begin{array}{l}\text { 1. Jumlah gerai SE di } \\
\text { Jakarta mencapai } \\
190 . \\
\text { 2. Tahun puncak } \\
\text { kejayaan. } \\
\text { 3. Pembukaan PT. FF } \\
\text { Indonesia }\end{array}$ & $\begin{array}{l}\text { Penjualan bersih pun } \\
\text { naik } 24,5 \text { persen } \\
\text { menjadi Rp. } 971,7 \\
\text { miliar dari tahun } \\
\text { sebelumnya yang } \\
\text { hanya Rp. } 778,3 \\
\text { miliar. }\end{array}$ \\
\hline 2015 & $\begin{array}{l}\text { 1. Peluncuran produk } \\
\text { pertama PT. } \\
\text { FFIndonesia } \\
\text { 2. } 20 \text { gerai ditutup, } \\
\text { masih terdapat } 188 \\
\text { gerai. } \\
\text { 3. April } 2015 \\
\text { Larangan penjualan } \\
\text { minuman beralkohol } \\
\text { di gerai ritel modern } \\
\text { kecil seperti 7- } \\
\text { Eleven. }\end{array}$ & $\begin{array}{l}\text { 1. Menyelamatkan } \\
\text { bisnis dengan } \\
\text { strategi } \\
\text { restrukturisasi } \\
\text { dan konsolidasi } \\
\text { perusahaan, } \\
\text { termasuk secara } \\
\text { aktif mencari } \\
\text { investor baru } \\
\text { untuk melakukan } \\
\text { pengembangan } \\
\text { bisnis. }\end{array}$ \\
\hline
\end{tabular}




\begin{tabular}{|c|c|c|}
\hline Thn & Peristiwa & Detil Peristiwa \\
\hline & & $\begin{array}{l}\text { 2. Menurun daya beli } \\
\text { konsumen karena } \\
\text { situasi ekonomi } \\
\text { sedang melemah } \\
\text { terlebih daya saing } \\
\text { yang tinggi antar } \\
\text { minimarket, } \\
\text { sehingga } \\
\text { perusahaan } \\
\text { mengevaluasi } \\
\text { kinerja toko yang } \\
\text { tidak mencapai } \\
\text { target untuk } \\
\text { mengurangi biaya } \\
\text { operasional. } \\
\text { 3. Penurunan } \\
\text { penjualan akibat } \\
\text { larangan penjualan } \\
\text { minuman } \\
\text { beralkohol di } \\
\text { minimarket, diatur } \\
\text { dalam Peraturan } \\
\text { Menteri } \\
\text { Perdagangan No. } \\
\text { 06/M- } \\
\text { DAG/PER/1/2015 } \\
\text { tentang } \\
\text { Pengendalian dan } \\
\text { Pengawasan } \\
\text { terhadap } \\
\text { Pengadaan, } \\
\text { Peredaran, dan } \\
\text { Penjualan Minol. } \\
\text { Aturan tersebut } \\
\text { mulai berlaku } \\
\text { efektif } 17 \text { April } \\
\text { 2015. } \\
\text { 4. Penjualan turun } \\
\text { menjadi Rp. 886,84 } \\
\text { miliar. }\end{array}$ \\
\hline 2016 & $\begin{array}{l}\text { 1. } 25 \text { gerai ditutup } \\
\text { 2. Penurunan } \\
\text { penjualan sebesar } 28 \\
\text { persen. }\end{array}$ & $\begin{array}{l}\text { Hingga } 31 \text { Desember } \\
\text { 2016, jumlah outlet } \\
\text { SE menjadi } 161 \\
\text { gerai. Kebutuhan } \\
\text { masyarakat urban } \\
\text { yang serba cepat dan } \\
\text { mengutamakan } \\
\text { kecepatan pelayanan, } \\
\text { kenyamanan dan } \\
\text { kualitas produk yang } \\
\text { baik dan konsisten } \\
\text { terus meningkat } \\
\text { sehingga memberikan } \\
\text { peluang pasar yang } \\
\text { menjanjikan untuk } \\
\text { bidang usaha ritel ini } \\
\text { kedepannya. }\end{array}$ \\
\hline
\end{tabular}

\begin{tabular}{|l|l|l|}
\hline \multicolumn{1}{|c|}{ Thn } & \multicolumn{1}{|c|}{ Peristiwa } & \multicolumn{1}{c|}{ Detil Peristiwa } \\
\hline $\begin{array}{l}\text { awal } \\
\text { thn } \\
2017\end{array}$ & $\begin{array}{l}\text { Sebanyak 30 gerai } \\
\text { tutup. }\end{array}$ & $\begin{array}{l}\text { tidak dapat mencapai } \\
\text { target perusahaan. }\end{array}$ \\
\hline 30 & $\begin{array}{l}\text { Seluruh gerai SE } \\
\text { Juni } \\
2017\end{array}$ & \\
\hline
\end{tabular}

Sumber: Modern Internasional Anual Report 2015

Gambar 1.1

Jumlah Gerai dan Hasil Penjualan Di

SE
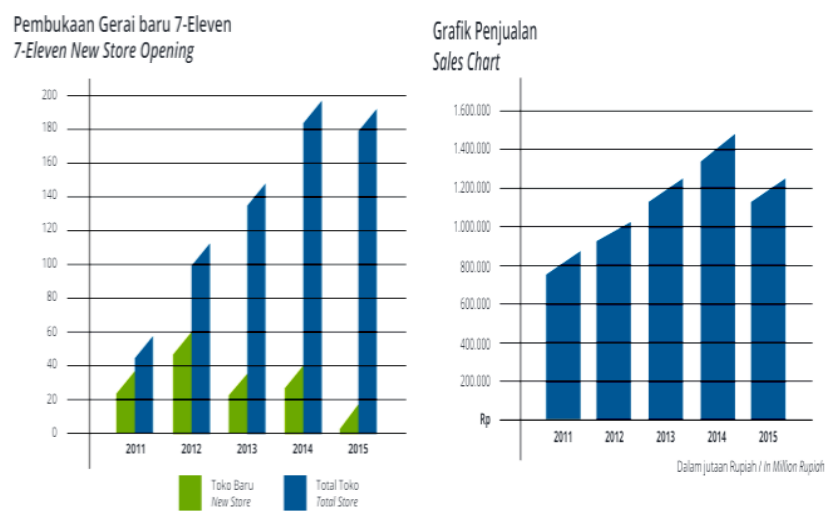

Sumber: Modern Internasional Anual Report 2015

\section{Rumusan Masalah}

Identifikasi dan rumusan masalah antara lain: merujuk pada fenomena yang terjadi terhadap produk-produk baru dan model bisnis baru yang dibawa oleh perusahaan asing, lalu mendapatkan perhatian dari konsumen Indonesia sangat besar dan diterima dengan baik, namun pada batas waktu tertentu mengalami penurunan bahkan menghilang akibat pengikut pasar yang berasal dari Indonesia. Harga yang lebih terjangkau disesuaikan dengan tingkat ekonomi konsumen menyebabkan konsumen beralih ke produk pengikut walaupun kualitas di bawah produk perintis. Penulisan ini mengambil contoh kasus convenience store SE yang dievaluasi karena keberadaannya mempengaruhi gaya hidup masyarakat kota Jakarta sehingga tidak diperkirakan operasionalnya akan ditutup. Dengan demikian rumusan masalahnya sebagai berikut:

1. Bagaimana Product Life Cycle (PLC) dari bisnis SE dengan kemampuan competitive adventage strategies yang dimilikinya untuk menghadapi pesaing pasar?

2. Bagaimana melakukan antisipasi terhadap aksi dari kompetitor?

3. Strategi-strategi apa saja yang dapat direkomendasikan untuk pendatang baru? 


\section{Tujuan Penelitian}

Tujuan penulisan untuk mengevaluasi proses bisnis dari perusahaan dari luar negeri dalam menghadapi persaingan pasar dengan contoh kasus pada SE. Berikut tujuan dari penulisan ini:

1. Mengidentifikasi Product Life Cycle dari bisnis SE dengan kemampuan competitive adventage strategies yang dimilikinya untuk menghadapi pesaing pasar.

2. Menjelaskan penerapan antisipasi terhadap aksi dari kompetitor.

3. Menyusun strategi-strategi yang dapat direkomendasikan kepada produk luar dan menjadi pemimpin pasar dalam menghadapi pengikut pasar dari hasil antisipasi terhadap aksi dari kompetitor.

\section{TINJAUAN PUSTAKA}

\section{Siklus Hidup Produk (Product Life Cycle)}

Siklus hidup produk atau Product Life Cycle (PLC) merupakan jangka waktu suatu produk dan jasa berada di pasar. Setiap produk berbeda-beda ada yang cepat hilang dan ada yang dapat bertahan jangka waktu relatif lama. PLC memiliki standar tahapan mulai dari diperkenalkan kepada pasar sampai dengan hilang dari pasaran. Pada setiap tahap waktu PLC memiliki strategi bersaing yang berbeda. Empat tahapan umum PLC menurut Kho (2017) yang digunakan perusahaan dalam memasarkan produknya dengan membandingkan atara penjualan dan waktu bertahan produk: perkenalan (introduction), perkembangan (growth), kedewasaan (maturity) dan penurunan (decline). Fase atau siklus dari PLC:

\section{Gambar 2.1}

Product Life Cycle

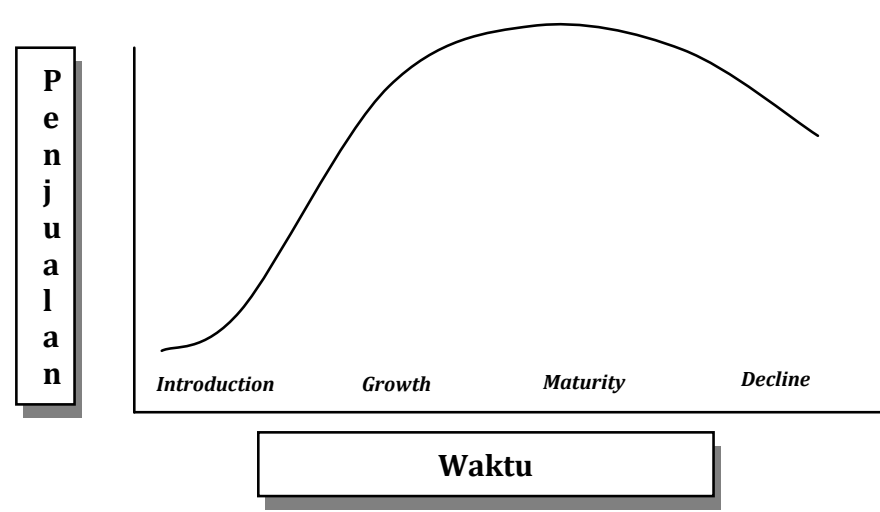

Sumber: Marketing Management 9e
Dan pada Tabel 2 adalah karakteristik dari setiap fase:

Tabel 2.1

Karakteristik Produk Life Cycle

\begin{tabular}{|c|c|c|c|c|}
\hline Karakteristik & Perkenalan & Pertumbuhan & Kemapanan & Penurunan \\
\hline Penjualan & $\begin{array}{l}\text { Penjualan } \\
\text { rendah }\end{array}$ & $\begin{array}{l}\text { Penjualan } \\
\text { meningkat } \\
\text { cepat }\end{array}$ & $\begin{array}{l}\text { Puncak } \\
\text { penjualan }\end{array}$ & $\begin{array}{l}\text { Penjualan } \\
\text { menurun }\end{array}$ \\
\hline Biaya & $\begin{array}{l}\text { Biaya tinggi } \\
\text { per } \\
\text { pelanggan }\end{array}$ & $\begin{array}{l}\text { Biaya rata-rata } \\
\text { per pelanggan }\end{array}$ & $\begin{array}{l}\text { Biaya rendah } \\
\text { per } \\
\text { pelanggan }\end{array}$ & $\begin{array}{l}\text { Biaya } \\
\text { rendah per } \\
\text { pelanggan }\end{array}$ \\
\hline Laba & $\begin{array}{l}\text { Negatif atau } \\
\text { kecil untuk } \\
\text { promo }\end{array}$ & $\begin{array}{l}\text { Laba } \\
\text { meningkat }\end{array}$ & Laba tinggi & $\begin{array}{l}\text { Laba } \\
\text { menurun }\end{array}$ \\
\hline Pelanggan & Inovasi & Pemakai awal & $\begin{array}{l}\text { Mayoritas } \\
\text { menengah }\end{array}$ & $\begin{array}{l}\text { Pemakai } \\
\text { terlambat }\end{array}$ \\
\hline Pesaing & Sedikit & $\begin{array}{l}\text { Jumlahnya } \\
\text { bertambah }\end{array}$ & $\begin{array}{l}\text { Jumlah stabil } \\
\text { mulai } \\
\text { menurun }\end{array}$ & $\begin{array}{l}\text { Jumlahnya } \\
\text { menurun }\end{array}$ \\
\hline
\end{tabular}

Sumber: Marketing Management 9e

\section{Produk Pelopor (Pionner) dan Produk Pengikut (Follower)}

Produk perintis adalah produk yang dipersiapkan untuk menjadi produk pemimpin pasar saat diperkenalkan, konsumen secara cepat menemukan kecocokan terhadap produk tersebut. Respon konsumen dapat menentukan apakah produk tersebut menjadi pemimpin pasar atau sebagai pengikut, sehingga penentuan waktu yang tepat untuk berada di pasar menjadi kunci kesuksesan produk berada di pasar. Pilihan suatu produk menjadi pemimpin pasar dipengaruhi perubahan lingkungan untuk melakukan langkah pertama masuk ke dalam pasar (Kalicanin, D). Langkah-langkah awal untuk menjadi produk perintis antara lain: membuat produk baru dengan fokus pada diferensiasi strategi sehingga produk tersebut menjadi prototipe, mempunyai jalur pasokan dan distribusi dengan jaringan yang cakupan lebih baik, memiliki kreatifitas berdasarkan loyalitas konsumen, memiliki kemampuan sulit untuk diikuti oleh pesaing, menciptakan permintaan produk baru yang lebih besar, teknologi yang dapat mengalihkan biaya produksi dalam menghadapi pesaingnya dan peningkatan pertumbuhan penjualan, waktu dan aktifitas, lokasi, manajemen dan karyawan, keunggulan kompetitif selalu dipelihara agar product life cycle pada produk tersebut dapat bertahan lebih lama (Kalicanin, D). Demikian pula menurut pendapat Adner dalam Kuntjoroadi (2009) bahwa strategi pembuatan produk inovasi baru memiliki resiko penerimaan konsumen dan loyalitas dari konsumen, investasi yang besar untuk 
melakukan inovasi dari pada jiplak, mempelajari kemampuan pasar dan uji coba terhadap produk mengeluarkan biaya untuk iklan dan promosi, sedangkan produk pengikut menikmati kesempatan dari aktivitas produk baru tersebut. Pendapat Adner tersebut didukung oleh penulisan pada oxbowpartners (2018) bahwa proses baru yang diciptakan walaupun sulit untuk diikuti oleh produk pengikut tetap akan memberikan kesempatan untuk diikuti, membuat pasar baru untuk permintaan baru dengan melakukan penelitian terlebih dahulu sehingga dapat memprediksi resiko yang terjadi dan memperoleh laba yang sedang berkembang. Kemudian dalam waktu tertentu pengaruh faktorfaktor eksternal yang dihadapi oleh pemimpin pasar ketika memberikan kesempatan produk lain sebagai produk pesaing untuk memenangkan persaingan, seperti faktor-faktor berikut ini: a) produk pengikut pasar secara bebas menjiplak aktifitas produk pelopor, b) ada ketidak pastian di pasar terhadap perkembangan produk dan teknologinya, c) perubahan yang tidak terduga atas perubahan teknologi dan kebutuhan konsumen, d) kemampuan bertahan untuk mengikuti perkembangan teknologi (Kerin et al, 1992: 47 dalam Kalicanin, D). Masuknya pengikut pasar mempengaruhi sebagian besar keunggulan kompetitif dari produk perintis, hal ini disebabkan strategi-strategi keunggulan kompetitif tersebut digunakan oleh produk pengikut untuk mengeluarkan produknya, seperti: 1) melakukan perbandingan antara biaya inovasi dan biaya imitasi; 2) memanfaatkan penghematan biaya inovasi; 3) memanfaatkan kesalahan perintis; 4) manfaat dari ekonomi ruang lingkup; 5) mempengaruhi/merubah preferensi konsumen. Secara umum strategi yang dibentuk oleh pengikut pasar secara umum adalah low-cost strategies (analogous to Kaplan, Norton, 2004 dalam Kalicanin, D). Kegagalan dari produk perintis saat menghadapi produk pesaing, sehingga harus membagi keuntungan secara cepat dikarenakan: 1) perintis tidak menawarkan tingkat layanan pelanggan yang superior or prima; 2) teknologi baru bisa mengimbangi biaya sehingga menyediakan pelayanan yang dapat menurunkan biaya; 3) new entrant mengembangkan cara baru untuk akses ke pasar dengan inovasi strategi distribusi; 4) pengikut/pendatang baru mungkin hanya menentukan harga secara agresif, menargetkan segmen yang dipilih dengan mengambil keuntungan dari kecenderungan inkuben untuk harga rata-rata untuk di semua segmen; 5) banyak merek yang tersedia sehingga reaksi konsumen menjadi bingung. Pada Gomez dan Ramirer, 2014 menjelaskan bahwa pemimpin pasar yang mendapat rata-rata $33 \%$ untuk 5 tahun pertama jika produk masuk lebih lambat 6 bulan, namun jika masuk tepat waktu tetapi melampaui biaya produk sehingga memotong $4 \%$ dari penghasilan. Salah satu hasil dari survei yang dilakukan oleh carpenter dan nakamoto dalam Gomez dan Ramirer, 2014 tercantum bahwa terdiri 19-25 perusahaan bertahan selama 60 tahun sebagai pemimpin pasar. Sedangkan menurut Robinson dan Fornell dalam Gomez dan Ramirer, 2014 mendapati bahwa $66 \%$ produk perintis bisa bertahan selama 10 tahun dan produk pengikut sebanyak $45 \%$. Dari beberapa penulisan tersebut di atas, berikut perbedaan strategi produk perintis dengan produk pengikut dalam merebut pasar dirangkum pada tabel berikut:

Tabel 2.2

Perbedaan Strategi Produk Perintis dengan Produk Pengikut

\begin{tabular}{|c|c|}
\hline Produk Perintis & Produk Pengikut \\
\hline $\begin{array}{l}\text { 1. Mengadopsi } \\
\text { teknologi baru yang } \\
\text { bisa mengimbangi } \\
\text { biaya sehingga } \\
\text { dapat menurunkan } \\
\text { total pengeluaran. }\end{array}$ & $\begin{array}{l}\text { 1. } \text { Melakukan } \\
\text { perbandingan } \\
\text { antara biaya } \\
\text { inovasi dan biaya } \\
\text { imitasi. }\end{array}$ \\
\hline $\begin{array}{l}\text { 2. Menciptakan } \\
\text { produk baru yang } \\
\text { lebih baik dengan } \\
\text { fokus pada strategi } \\
\text { diferensiasi, } \\
\text { sehingga produk } \\
\text { perintis menjadi } \\
\text { prototipe. }\end{array}$ & $\begin{array}{l}\text { 2. Memanfaatkan } \\
\text { penghematan biaya } \\
\text { inovasi. }\end{array}$ \\
\hline $\begin{array}{l}\text { 3. Perlu waktu yang } \\
\text { tepat untuk berada } \\
\text { di pasar agar } \\
\text { aktifitas awal } \\
\text { produk baru } \\
\text { seperti: promosi } \\
\text { awal/perkenalan } \\
\text { awal uji coba } \\
\text { produk dengan } \\
\text { penjualan rendah, } \\
\text { sesuai kebutuhan } \\
\text { konsumen agar } \\
\text { konsumen sebagai } \\
\text { pembeli yang siap } \\
\text { membeli. }\end{array}$ & $\begin{array}{l}\text { 3. Memanfaatkan } \\
\text { kesalahan perintis, } \\
\text { sehingga produk } \\
\text { pengikut } \\
\text { menikmati } \\
\text { kesempatan untuk } \\
\text { membuat dan } \\
\text { memperbaiki } \\
\text { produknya secara } \\
\text { kontiniu. }\end{array}$ \\
\hline
\end{tabular}




\begin{tabular}{|c|c|}
\hline Produk Perintis & Produk Pengikut \\
\hline $\begin{array}{l}\text { 4. Produk baru } \\
\text { membuat pasar } \\
\text { baru yang luas } \\
\text { untuk permintaan } \\
\text { baru sehingga dapat } \\
\text { sesuai dengan } \\
\text { pangsa pasarnya. } \\
\text { Target pasar yang } \\
\text { tepat untuk dipilih } \\
\text { dapat mengambil } \\
\text { keuntungan. }\end{array}$ & $\begin{array}{l}\text { 4. Memanfaatkan } \\
\text { kondisi ekonomi } \\
\text { sebagai } \\
\text { kesempatan } \\
\text { pengikut/pendatan } \\
\text { g baru menentukan } \\
\text { harga secara } \\
\text { agresif dengan } \\
\text { harga yang lebih } \\
\text { rendah. }\end{array}$ \\
\hline $\begin{array}{l}\text { 5. Menggunakan } \\
\text { proses baru untuk } \\
\text { produk dan } \\
\text { pelayanan yang } \\
\text { superior or prima } \\
\text { agar mendapatkan } \\
\text { kepuasan } \\
\text { konsumen, } \\
\text { sehingga konsumen } \\
\text { tidak akan beralih } \\
\text { pada produk yang } \\
\text { baru. }\end{array}$ & $\begin{array}{l}\text { 5. Mempengaruhi } \\
\text { atau merubah } \\
\text { preferensi } \\
\text { konsumen. }\end{array}$ \\
\hline $\begin{array}{l}\text { 6. Produk baru juga } \\
\text { mengembangkan } \\
\text { cara baru untuk } \\
\text { akses ke pasar } \\
\text { dengan inovasi } \\
\text { strategi distribusi, } \\
\text { mencari } \\
\text { pemasok/penjual. }\end{array}$ & $\begin{array}{l}\text { 6. Strategi yang } \\
\text { dibentuk oleh } \\
\text { pengikut pasar } \\
\text { secara umum } \\
\text { adalah low-cost } \\
\text { strategies. }\end{array}$ \\
\hline $\begin{array}{l}\text { 7. Biaya produksi } \\
\text { dialihkan untuk } \\
\text { biaya menghadapi } \\
\text { pesaingnya dan } \\
\text { pertumbuhan } \\
\text { penjualan. }\end{array}$ & $\begin{array}{l}\text { 7. Menggunakan } \\
\text { kekuatan pasar } \\
\text { yang untuk } \\
\text { menyalip produk } \\
\text { perintis. }\end{array}$ \\
\hline $\begin{array}{l}\text { 8. Keunggulan } \\
\text { kompetitif selalu } \\
\text { dipelihara, agar } \\
\text { product life cycle } \\
\text { pada produk } \\
\text { tersebut dapat } \\
\text { bertahan lebih } \\
\text { lama. }\end{array}$ & \\
\hline
\end{tabular}

Sumber: Olahan Resume Literasi

\section{Competitive Advantages Strategy}

Penulisan ini mengidentifikasikan keunggulan bersaing melalui berbagai atribut dan sumber daya yang berbeda dan sulit untuk diikuti yang lain di pasar yang sama baik yang dimiliki produk perintis maupun produk pesaing untuk pelanggan untuk mendapatkan profit yang besar juga bagi perusahaan (Chaharbaghi, K., Lynch R., dalam Braslina, 2014). Keunggulan bersaing ada pada saat perusahaan mampu menawarkan keunggulan biaya yaitu memperoleh manfaat yang lebih dengan biaya barang yang lebih rendah; atau keunggulan diferensiasi. Beberapa sumber keunggulan bersaing seperti teknik produksi yang lebih efisien, citra merek, loyalitas konsumen dan lokasi (Black, J., Hashimzade, N., Myles, G., dalam Braslina, 2014) Perusahaan melakukan lebih banyak aktifitas yang menciptakan ratai nilai (value chain) seperti merancang, memasarkan dan mendukung produk perusahaan dibandingkan dengan perusahaan pesaing sehingga pembeli memperoleh nilai lebih dari jumlah yang dibayarkan. Keunggulan bersaing dibangun dalam dua kelompok kegiatan perusahaan yaitu kegiatan utama dengan penciptaan fisik produk termasuk bentuk penjualan dan purna jual, serta kegiatan pendukung seperti menyediakan input yang dibeli, teknologi, sumber daya manusia dan fungsi terkait lainnya (Porter M.E. 1998). Keunggulan bersaing untuk perusahaan menurut konsep dari Porter adalah suatu posisi dimana sebuah perusahaan menguasai sebuah ajang persaingan bisnis dan perusahaan mampu: memberikan manfaat yang sama dengan pesaing tetap dengan biaya barang yang lebih rendah (keunggulan biaya) atau memberikan manfaat yang melebihi produk pesaing dengan diferensiasi produk sehingga produk menjadi unik atau dalam bentuk layanan yang menawarkan segala bentuk atribut unik yang dihargai oleh pelanggan yang lebih baik dari pesaingnya (keunggulan diferensiasi), seberapa luas segmen pasar yang dilayani perusahaan. Sementara menurut Garry L. Adams dalam Braslina, 2014, bahwa keunggulan bersaing juga merujuk pada pembelajaran berbasis budaya. Keunggulan bersaing akan dinilai lebih bila dibandingkan dengan pesaing jika perusahaan telah menentukan siapa pesaing yang kompeten untuk dijadikan pembanding. Dua kekuatan utama yang menyebabkan perubahan keunggulan bersaing pada lingkup persaingan adalah perubahan kebijakan dan teknologi publik serta ditambah dengan adanya gangguan terus menerus akibat globalisasi, permintaan pelanggan dan saluran distribusi. Hal ini menyebabkan kompetisi menjadi lebih dinamis, batas-batas area persaingan menjadi lebih tidak jelas, pesaing semakin sulit untuk diidentifikasi atau diantisipasi. 
1. Dari sisi permintaan konsumen area persaingan ditentukan dari pola kebutuhan konsumen yang dilayani dengan menyediakan berbagai penawaran dari produk yang kompetitif termasuk memberikan pelayanan sampai akhirnya konsumen memutuskan untuk membeli. Semua bentuk aktivitas yang disediakan oleh perusahaan dapat memberikan manfaat bagi konsumen, harga yang diciptakan sesuai dengan manfaat, sehingga konsumen bersedia membayar lebih.

2. Dari sisi permintaan, arena persaingan dimulai dengan kemampuan pasokan melayani kebutuhan sekelompok konsumen. Dengan prespektif penawaran antara lain: a) mengamati penawaran pelayanan produk oleh pesaing seperti teknologi, proses pembuatan, sumber bahan, tenaga penjualan dan saluran distribusi yang sama; b) letak geografi pasar; c) memilih pesaing yang memiliki kapasitas bersaing.

Keunggulan bersaing yang berkelanjutan (sustainable competitive advantage) adalah keunggulan yang tidak mudah ditiru, membuat suatu perusahaan dapat merebut dan mempertahankan posisinya sebagai pimpinan pasar. Perusahaan tidak hanya memiliki teknik perencanaan yang berbeda tetapi dikaitkan dengan perencanaan strategis dari manajemen untuk pengambilan keputusan operasional. Tiga mekanisme perencanaan strategis menurut S.Day (1997) untuk pengambilan keputusan operasional:

1. Perusahaan melakukan kerangka kerja perencanaan yang berbeda sehingga dapat mempengaruhi keputusan dari konsumen. Pola tingkatan pengaturan proses perencanaan strategis perusahaan:

a. Perencanaan produk/pasar merupakan perencanaan strategis yang terendah, yang ditentukan oleh produk, harga, penjualan, layanan, identifikasi kompetitor dan dipengaruhi oleh pergerakan ekonomi.

b. Perencanaan unit bisnis perusahaan.

c. Perencanaan sumber daya bersama, bertujuan untuk menghindari perubahan ekonomi yang menyebabkan masa kritis dengan melakukan pengelolaan sumber daya perusahaan secara keseluruhan.

d. Perencanaan fokus perusahaan, diperlukan tingkat tanggungjawab perencanaan yang berbeda seperti dengan adanya teknologi yang digunakan oleh sejumlah unit bisnis.

e. Perencanaan tingkat perusahaan dengan mengidentifikasi tren pasar secara global, menetapkan tujuan perusahaan, mengatur sumber daya keuangan dan manusia yang mendukung tujuan perusahaan.

2. Proses Perencanaan

Proses perencanaan pada perusahaan disusun selengkap mungkin dan fleksibel serta kreatif. Proses perencanaan strategis secara formal dihubungkan dengan kalender perusahaan untuk menyelesaikan sesuai tujuan perusahaan dan tersusun secara efektif setiap tahun.

3. Sistem Penilaian Perusahaan, memperkuat terlaksananya perencanaan perusahaan

Lima analisis kekuatan dalam persaingan menurut Porter dengan cara mengolah kebutuhan dari konsumen, terdiri dari yang menentukan intensitas persaingan dalam suatu industri yaitu ancaman produk pengganti, ancaman pesaing, ancaman pendatang baru, daya tawar pemasok dan daya tawar konsumen. Kelima analisis kekuatan Porter ini dapat menentukan daya tarik keseluruhan area persaingan pada gambar berikut:

Gambar 2.2

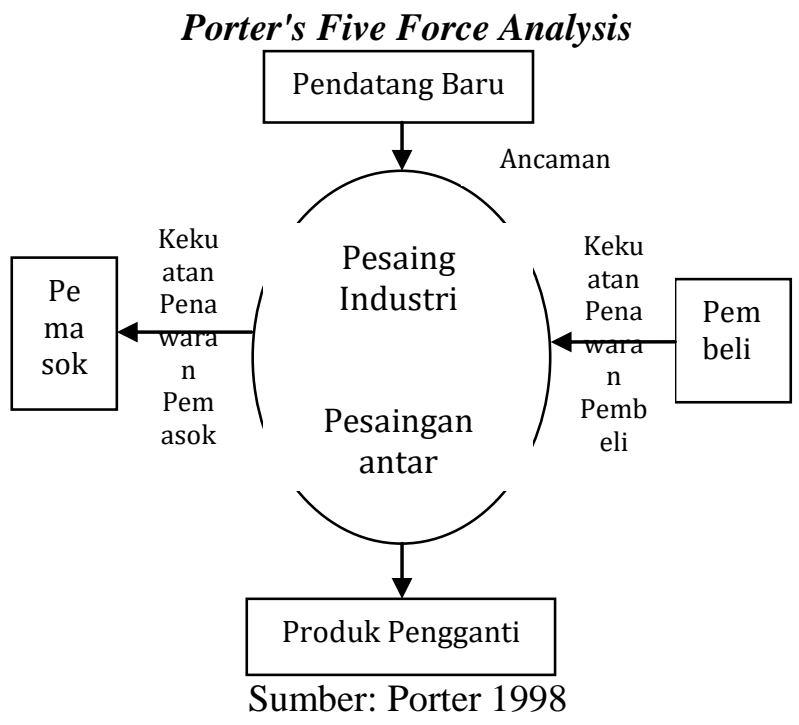

\section{METODE PENELITIAN}

\section{Metode Penelitian}

Pendekatan penulisan ini adalah deskriptif melalui pendekatan evaluasi terhadap kasus dengan menggunakan teori dan literasi yang berperan memberikan petunjuk untuk mengembangkan pemikiran, merancang disain, mengumpulkan data dan mengalisis hingga menguji keabsahan teori tersebut. Irawan dalam Kuntjoroadi (2009) menjelaskan tujuan dari penelitian deskriptif adalah menjelaskan satu objek secara relatif mendalam dan terfokus pada objek kajian terbatas. Tujuan dari 
penulisan ini untuk membuat gambaran secara sistematis, mengenai fakta-fakata serta hubungan dengan fenomena yang diselidiki. Studi kasus terhadap model bisnis pemimpin pasar yang memiliki produk-produk namun tidak lama bertahan menghadapi pesaing pasar. Dengan mengambil contoh kasus convenience store $\mathrm{SE}$ dikaji ulang berdasarkan teori-teori yang ada (literature review) sehingga menghasilkan strategistrategi umum yang dapat digunakan oleh produk lain yang mengalami hal yang sama. Contohcontoh produk lain yang berinisial seperti $\mathrm{C}$ dan $\mathrm{K}$ (sepatu), S café, B (perawatan badan dan muka) adalah produk-produk yang akhirnya terkalahkan oleh pengikut pasar dan keberadaannya dalam persaingan sudah mulai surut dari perhatian konsumen Indonesia. Teori-teori pendukung dalam penulisan ini yaitu siklus produk (product life cycle), strategi-strategi kompetitif, serta antisipasi terhadap aksi kompetitor untuk menyusun kembali strategi-strategi yang dapat direkomendasikan secara umum. Pengumpulan data dengan cara studi kepustakaan yang dipergunakan untuk mengumpulkan data sekunder. Dengan pola pikir sebagai berikut:

Gambar 3.1

Pola Pikir Penulisan

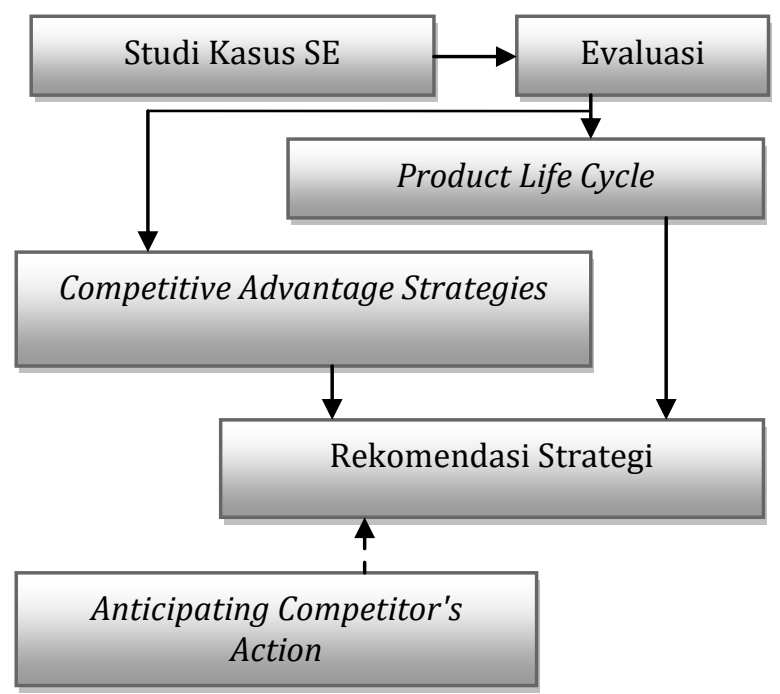

Sumber: Olahan Penulis

\section{HASIL DAN PEMBAHASAN}

\section{Evaluasi Product Life Cycle SE}

Convenience store SE sebagai unit bisnis dari perusahaan PT. MPI juga mengalami produk life cycle (siklus hidup produk). Secara waktu SE cuma mampu bertahan selama 9 tahun. Karakteristik siklus hidup SE berdasarkan jumlah gerai dan jumlah penjualan menunjukan peningkatan minat konsumen, maka kondisi SE seperti berikut:

\section{Perkenalan}

Fase perkenalan produk bisnis SE dimulai tahun 2008 saat penandatanganan sampai dengan akhir 2009. Pada fase ini SE sudah mendapatkan perhatian masyarakat Jakarta. Konsumen merasakan hal yang baru dengan adanya Convenience store 24 jam ini antara lain: inovasi dari segi pelayanan, menyediakan makanan dan minuman berkonsep fresh food seperti slurpee, kripik kentang dengan saus keju dan saus sambal, nasi tenggo, 7fresh, big bite, gulp minuman beralkohol dengan harga di bawah cafe, menyediakan tempat 'nongkrong' baru untuk konsumen dengan jaringan internet gratis, menyediakan teknologi yang baru, tata letak produk, serta brand image yang sudah dimiliki memudah Convenience store ini untuk memperkenalkan diri dengan bentuk promosi dari inovasi yang diberikan. Hal-hal baru lainnya seperti membangun trend anak muda sehingga tidak menyebabkan konsumen untuk mempertimbangkan biaya yang akan dikeluarkan, ketersediaan inovasi yang berbeda serta pesaing yang masih sedikit. Dengan demikian dimasa perkenalan ini biasanya produk akan mengalami profit yang negatif dan penjualan yang rendah tidak berlaku untuk SE. Respon yang baik dari pelanggan menyebabkan kriteria-kriteria fase perkenalan justru terbalik. SE menjadi pemimpin pasar bisnis convenience store menyaingi CK. SE dapat dinyatakan sebagai produk perintis, dikarenakan memiliki teknologi yang dapat mengurangi biaya dan memperkenalkan proses yang baru, produk baru yang menjadi prototipe pada bentuk bisnisnya, mendapat respon yang cepat dari konsumen dengan target yang tepat yaitu menengah ke atas dan para pekerja.

\section{Pertumbuhan}

Pertumbuhan SE sangat cepat, tahun 2009 sudah memperlihatkan keberhasilan membangun minat pasar secara massal. Perkembangan ditunjukan dari penambahan gerai sebanyak 57 gerai yang tersebar di kota Jakarta pada tahun 2010 sampai dengan 2011 (tahap pertumbuhan SE). SE menjadi pengusung awal conviniene store yang mengedepankan ruang ritel yang dikombinasikan dengan public space yang menjamin penawarkan produk dan pelayanan sehingga konsumen merasa 
istimewa walaupun harga masih lebih tinggi, menciptakan budaya hangout, memaksimalkan pangsa pasar yang ada bahkan memasuki segmen baru yaitu mulai bawah sampai dengan atas dengan batasan usia yang beragam. Dengan bertambahnya gerai menunjukan pertumbuhan keuntungan, pertumbuhan yang cepat menarik minat pesaing untuk meniru konsep bisnisnya. Para pesaing yang baru memasuki pasar, tertarik terhadap kesempatan memperoleh keuntungan berskala besar. Contoh pesaing baru seperti Lawson, Family Mart dengan konsep yang sama dan berasal dari negara yang sama pula. Bahkan conviniene store asal Indonesia pun mulai meniru konsepnya, mulai dari produk minuman terlebih dahulu.

\section{Kemapanan}

Tahun 2012 sampai dengan tahun 2014 merupakan fase kemapanan, karena pada fase ini terus mengalami keuntungan yang tinggi. Tahun 2014 sebagai puncak penjualan Rp. 971,7 miliar. Di tahun 2014 juga semakin banyak gerai dengan konsep yang serupa baik dari brand lokal maupun brand internasional, maka beberapa strategi yang dilakukan antara lain mempertahankan dan menambah pangsa pasar, mendirikan usaha bisnis baru PT. Fress Food Indonesia sebagai distributor gerai dan sebagai peningkatan kualitas serta keistimewaan produk, sehingga dapat memperluas keragaman produknya, adanya promosi untuk beberapa produknya yang menjadi keistimewaannya dari awal perkenalan, tetap memberikan pelayanan yang prima yang sudah menjadi standar dari SE. Namun pengaruh pesaing pasar sebagai pengikut sudah semakin banyak di fase ini.

\section{Gambar 4. Laba Bruto SE}

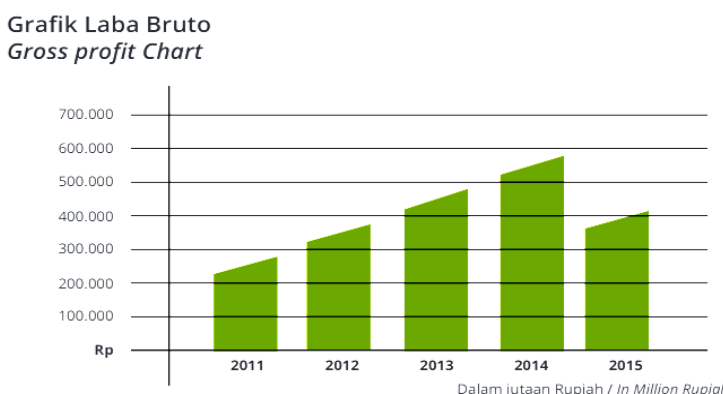

Sumber: Modern Internasional Anual Report 2015

\section{Penurunan}

Tahun 2015 awal penurunan penjualan diikuti pernurunan keuntungan, akibat dari pengaruh perubahan kebijakan pemerintah tentang pelarangan penjualan minumal beralkohol pada conviniene store yang berakibat kehilangan penjualan makanan ringan yang biasa dibeli bersama minuman tersebut. Alasan lain penurunan disebabkan perkembangan teknologi yang sudah diikuti oleh pesaing, pergeseran selera konsumen khususnya konsumen yang lebih mencari harga terendah namun mendapatkan pelayanan yang sama, meningkatnya persaingan dalam negeri dan luar negeri akibatnya kelebihan kapasitas, mengikatnya perang harga dan erosi laba. Akibatnya SE sampai dengan 2017 berusaha untuk melakukan perbaikan strateginya untuk mengurangi biaya dengan cara melakukan penutupan beberapa gerai yang tidak aktif, mencari investor, fokus layanan baru dengan Grab, pembelian online ticket, mengeluarkan produk baru fresh food, mengurangi tempat untuk nongkrong, atau mulai mengurangi biaya operasional. Upaya untuk ekspansi selain kota Jakarta belum dapat dilakukan, karena adanya produk-produk lokal yang lebih dilirik oleh konsumen.

\section{Tabel 4.1}

\section{Laporan Penjualan Tahun 2015}

Tabel Laporan Penjualan Per Segmen Usaha Periode 2015 Table of Sales Report Per Business Sement Period 2015

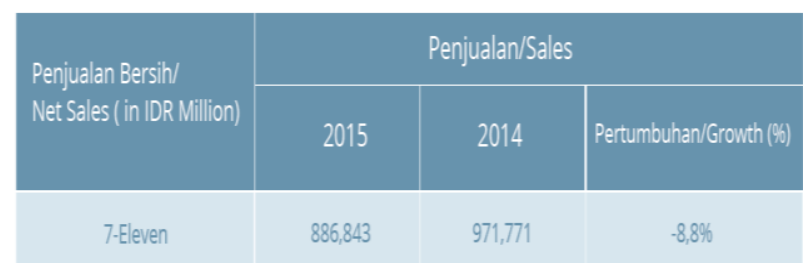

Sumber: Modern Internasional Anual Report 2015

Evaluasi Competitive Advantage Strategy 7Eleven Sebagai Pemimpin Pasar dalam Menghadapi Pesaing

Konsumen yang mendatangi convenience store adalah konsumen yang membeli barangbarang yang segera digunakan, untuk itu convenience store memaksimalkan kepuasan pelanggan dengan mengutamakan kecepatan layanan, kebersihan dan kerapihan store, keramahan pelayanan serta suasana yang menyenangkan termasuk didalamnya tempat dan fasilitas yang diberikan. Sejak awal SE telah memberikan keunggulan bersaing yang sangat kuat yaitu dengan memberikan inovasi-inovasi baru bagi konsumen Jakarta, seperti: keragaman produk selain consumer goods, juga menjual makanan cepat saji dengan meracik sendiri makanannya, harga produk yang masih terjangkau dengan pengalaman yang didapat, pemilihan gerai yang 
sangat strategis dengan standar operasi dan pelayanan yang sama, merata diseluruh operasi, promosi: tidak menggunakan iklan hanya memberikan keju cair gratis. Namun ketika sudah mulai masuk pesaing baru yang menjiplak hampir seluruh konsepnya, SE mulai kewalahan dan tidak bisa mempertahankan waktu lebih lama. S. Day (1997) menjelaskan bagaimana mengantisipasi aktivitas pesaing pada gambar berikut:

\section{Gambar 4.1}

\section{Anticipating Competitor's Actions}

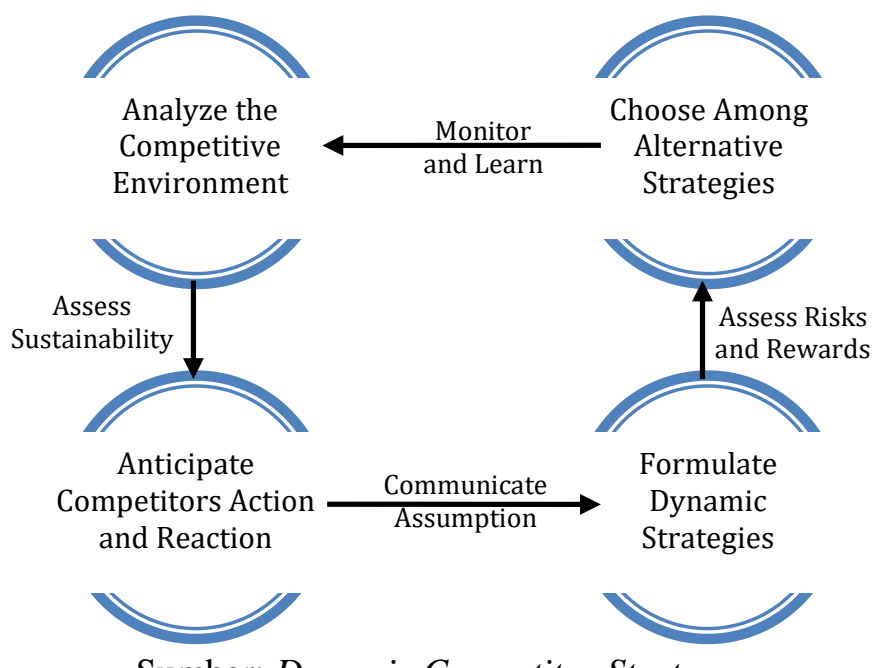

Sumber: Dynamic Competitve Strategy

Respon baik dari konsumen merupakan peluang untuk mengembangkan produknya, tapi mata pesaing juga mulai mengamati dan mempelajari bagaimana model bisnis ini bisa sukses. Fase pertumbuhan merupakan masa yang dinikmati namun mulai melakukan antisipasi dengan kemungkinan pesaing yang masuk. Proses antisipasi terhadap aksi pesaing antara lain:

1. Menyusun strategi yang dinamis berdasarkan asumsi-asumsi umum melalui pengamatan terhadap produk, kebutuhan konsumen, budaya dari masyarakat setempat. Secara umum budaya konsumen Indonesia pada segmen para pekerja atau memiliki kemampuan keuangan yang lebih tetap saja pemilihan harga menjadi pengaruh yang sangat kuat. Strategi-strategi setiap fase siklus bertujuan untuk peningkatan penjualan produknya, strategi yang dominan dilakukan untuk menghadapi pesaing dengan menunjukan peformance-nya melalui penambahan gerai dan unit bisnis pendukung distribusi, standarisasi pelayanan 24 jam dan ketersediaan jaringan internet serta tempat untuk berkumpul menghabiskan waktu, diferensiasi produk serta promosi produk.
2. Memilih alternatif strategi-strategi yang telah disusun dengan mempertimbangkan nilai-nilai resiko dan keuntungan yang akan diperoleh dari setiap strategi tersebut. Pemilihan strategi seperti tempat strategis, banyak produk yang ditawarkan, free wi-fi, pencahayaan yang terang, pelayanan yang ramah. Keunggulan kompetisi tersebut memiliki kelemahan seperti produk yang dijual cukup mahal, lahan parkir yang kecil, dibeberapa gerai lingkungan yang kotor, sirkulasi udara yang kurang baik, akses masuk yang cukup padat. Strategi penambahan gerai secara masif untuk pemenuhan kebutuhan konsumen memiliki dampak positif dan negatif. Performance perusahaan menunjukan bahwa model bisnisnya semakin meningkat, namun penambahan gerai telah mengurai jumlah konsumen yang berdampak pada penghasilan setiap gerai, penambahan biaya operasional. Sehingga penambahan jumlah gerai yang sangat banyak bukan menjadi strategi yang prima.

3. Melakukan analisis lingkup kompetisi dengan memonitor dampak dari strategi-strategi tersebut. Budaya pesaing yang sering ada adalah budaya copy cat (pengikut), produk yang ada ditiru dan disesuaikan dengan kemampuan daya beli konsumen, seluruh proses dan jenis produk serta distribusi bisa diikuti. Hal ini perlu menjadi perhatian sebab terjadi pengalihan konsumen ke pesaing. Ditambah lagi dengan kebijakan pemerintah yang melarang minuman beralkohol serta lingkup bisnis tidak bisa lebih dari kota Jakarta, sedangkan produk lokal bisa sampai ke pelosok daerah.

4. Mengantisipasi aksi dan reaksi dari pesaing melalui penilaian yang berkelanjutan. S. Day (1997) menjelaskan dalam menghadapi pesaing dapat dilakukan dengan mengabaikan pesaing, mengakomodasi pesaing atau melakukan pembalasan terhadap pesaing. Pada fase perkenalan sampai dengan pertumbuhan kecenderungan conviniene store ini seperti mengabaikan pesaing, dikarenakan menikmati tanggapan yang positif dari pelanggan. Pada fase kemapanan kecenderungan pesaing semakin agresif, jika sikap strategi yang diambil masih sama dengan penambahan gerai, justru menjadi ancaman seperti terdapat lokasi usaha yang sama dalam model bisnis yang sama juga disekitarnya sehingga mencari tempat yang strategis tapi sempit, harga yang tinggi dari produk yang dapat menurunkan potensi keuntungan dikarenakan monitoring dan kontrol setiap gerai harus rutin dilakukan agar sesuai dengan 
standarnya. Setelah mengalami penurunan baru melakukan retaliation dianggap sudah terlambat dikarenakan minat konsumen sudah banyak yang beralih seperti ke mini market berinisial "A" dan "I" yang sekarang masih bertahan. Produk pesaing mulai mengikuti sistem kerja SE, menyediakan tempat santai, tv termasuk produk fresh food yang ditawarkan. Sehingga sejak awal tidak perlu memberikan inovasi yang berlebihan.

\section{Rekomendasi Strategi untuk Menghadapi Pesaing Produk Pengikut}

Di Indonesia, khususnya kota besar, mini market tumbuh dengan pesat. Tidak hanya itu, retail sejenis, kedai kopi yang bukan berasal dari negara Indonesia juga ikut meramaikan arena kompetisi bisnis untuk mendapatkan perhatian dari konsumen. Pangsa pasar yang tidak terjangkau oleh produk pendatang awal dimanfaatkan oleh produk pengikut dengan kualitas tentunya di bawah produk aslinya dan ditambah variasi. Karena produk pengikut lebih waspada, mereka lebih memonitoring pasar dan akan cepat melakukan penanaman modal ketika siklus produk sedang bertahan, atau melihat peluang yang kesempatan mereka membangun produk yang sudah ada dan mengambil proposisi pasar niche serta memanfaatkan pembelajaran yang lebih luas dari para perintis. Hal ini terjadi tidak hanya SE sebagai contoh kasus tapi terjadi juga pada bentuk bisnis dan produk lain seperti, sepatu ber merek inisial "C" dan "K" yang sudah banyak diikuti oleh produk lokal, cafe berinisial "S" diikuti oleh cafe-cafe produk lokal dengan nama yang menarik. Dengan demikian perlu antisipasi yang dilakukan oleh perusahaan ketika produk diperkenalkan di pasar dengan melakukan analisis bersaing terhadap pesaing dihubungkan dengan cakupan ekonomi serta cakupan perilaku dari konsumen S. Day (1997). Analisis lingkup ekonomi berasal dari konsumen berupa informasi tentang kemampuan ekonomi sesuai dengan pangsa pasar yang dituju, pengaruh perubahan isu ekonomi global, sedangkan dari cakupan perilaku yaitu sikap dan minat yang ditujukan konsumen terhadap produk. Dari cakupan perilaku termasuk pengaruh budaya masyarakat Indonesia pada umumnya yang ingin trendy dengan harga terjangkau, sehingga strategi pada setiap fase produk secara umum sebagai berikut:

1. Tahap perkenalan produk merupakan penentuan pertama waktu yang tepat produk masuk ke pasar. Produk baru memiliki kemampuan bersaing jika produk terlalu agresif memberikan seluruh inovasinya, secara positif akan ditanggapi positif dari pelanggan namun pelanggan akan merasa cepat jenuh sementara itu kompetitor mencari keunggulan dengan pemotongan harga penawaran promosi, mengamati dan mencari peluang dari inovasi yang diberikan produk perintis. Konsumen sudah dibentuk dengan pola hidup dengan kebutuhannya pengaruh dari produk yang diberikan, untuk itu tidak perlu semua inovasi dikeluarkan sekaligus, perlu terlebih dahulu mengantisipasi tanggapan konsumen, memperlambat pesaing pengikut produk mempelajari inovasi yang sudah dikeluarkan oleh produk. Produk baru diperkenalkan melakukan beberapa strategi-strategi dalam mengatasi persaingan produknya atau tetap mempertahankan posisinya sehingga tidak dapat digoyahkan oleh produk pengikut, seperti: 1) membuat produk-produk baru, 2) menggunakan proses yang lebih mudah, 3) menemukan pasar konsumen yang baru (Heiens et al, 2003 dalam Kalicanin, D).

2. Pada tahap pertumbuhan, respon positif memberikan tingkat penjualan yang positif pula, maka ditambah inovasi baru lainnya untuk perluasan produk baik produk tunggal maupun layanan yang diberikan. Pertumbuhan yang semakin meningkat sangat diminati oleh pesaing terutama sebagai pengikut apalagi secara global kesempatan untuk masuk pasar sangat besar. Aksi untuk menekankan daya saing sudah mulai pada tahap ini dengan menyusun strategi entry barriers melalui pengamatan, mengumpulkan informasi siapa kompetitor yang paling utama dan analisis kemungkinan pengatasi setiap kerugian akibat pesaing. Strategi untuk mencegah pengikut pasar dengan melakukan permintaan yang berbeda dari yang ditawarkan, menggunakan produk sebagai uji coba, mulai memperluas pangsa pasar, perencanaan struktur biaya ketika biaya tetap tinggi, penekanannya pada pemanfaatan kapasitas, memperhatikan consumer insight yaitu bagaimana cara konsumen menggunakan sebuah produk atau jasa, tetapi juga bagaimana mereka menggunakan hal-hal lain untuk menggunakan produk. Consumer insight merupakan pendekatan yang sangat baik apabila ingin mendapatkan pemahaman yang dalam terhadap kehidupan, tingkah laku, dan sikap konsumen.

3. Ketika fase pertumbuhan masih sulit untuk diikuti, hal ini merupakan suatu keberhasilan 
dari produk untuk bertahan dan mendapatkan peningkatan keuntungan usaha. Ketika semua pesaing mengadopsi strategi produk perintis yang sama, maka secara alami memahami intensitas persaingan. Produk perintis dapat melakukan reaksi terhadap pesaing tersebut, seperti mulai memperhatikan kekuatan bersaing yang menjadi hambatan jika semua strategi telah diikuti oleh pesaing, biaya tenaga kerja atau modal yang lebih rendah, akses bahan baku, lokasi yang menguntungkan, atau hak paten terhadap teknologi yang dimiliki. Strategi untuk menghadapi pelanggan agar dikembangkan preferensi dan loyalitas yang kuat yang membuatnya lebih tahan terhadap penawaran pesaing, tingkat ketergantungan pada pengaruh penawaran dan kepekaan mereka terhadap harga. Segmen pasar kelas menengah bukanlah kelompok konsumen loyal nan fanatik, melainkan mudah berpindah dikarenakan konsumen menjadi lebih memiliki pengetahuan tentang produk sehingga kurang bersedia membayar harga lebih. Hal ini tentu butuh waktu, proses culture shifting tentu membutuhkan waktu dan proses yang tidak singkat. Strategi terhadap produk mulai melakukan produk diferensiasi, tidak hanya corak namun perlu inovasi bentuk. Produk pengikut justru lebih berani melakukan diferensiasi produk. Contohnya produk-produk lokal dengan kualitas di bawah namun bentuk secara sepintas tidak dapat dibedakan tidak dapat dipungkiri dapat mempengaruhi tingkat penjualan, mendorong lapis konsumen dari kalangan kelas menengah dengan wants (pilihan atas keinginan) yang melampaui needs (kebutuhan). Strategi penambahan gerai justru menambah biaya operasional, penyediaan sumber daya dan biaya pengendaliannya. Jadi sebelum melakukan penambahan jumlah gerai, perlu terlebih dahulu mengamati jumlah pelanggan dari hasil penjualan apakah meningkat disetiap gerai/outlet atau justru semakin berkurang. Bila dibandingkan di beberapa negara dan asal dari produk tidak perlu disetiap tempat terdapat gerai ini. Letak gerai dibagi setiap wilayah dengan jarak luasan tertentu. Satu hal yang tidak kalah pentingnya adalah siap tanggap terhadap perubahan regulasi pemerintahan.

4. Fase penurunan tidak hanya disebabkan faktorfaktor meredakan persaingan langsung, mereka juga menghalangi pendatang baru. Pengaruh intervensi pemerintah dengan persyaratan regulasi sering menjadi resiko tersendiri yang harus dipersiapkan. Pada fase ini merubah harga menjadi alternatif untuk menarik perhatian konsumen dengan penambahan kapasitas dan variasi produk, penambahan inovasi, termasuk kapasitas saluran distribusi walaupun dibangun unit bisnis tersendiri. Pada fase ini ekspansi besar-besaran tidak diperlukan lagi, justru lebih adaptif dalam membaca perubahan pasar, perlu pemikiran mengubah strategi mengubah daya tarik pasar agar produk tetap bertahan di pasar. Bahkan ketika tuntutan di pasar secara keseluruhan memburuk, masih ada segmen yang dapat dipertahankan dengan penawaran yang berbeda. Promosi, inovasi, penurunan harga serta mengurangi kerjasama atau operasional yang bermasalah.

Secara umum strategi-strategi terhadap produk perintis saat masuk pasar sebagai berikut:

1. Produk yang ditawarkan termasuk didalamnya proses pelayanannya, teknologi yang digunakan untuk mempermudah proses dan mengurangi total biaya, sistem saluran distribusi, menciptakan loyalitas konsumen, memiliki strategi yang mampu menghalangi masuknya pesaing yang menduplikasi.

2. Ketepatan waktu untuk masuk ke pasar adalah hal yang penting karena, keuntungan menjadi produk perintis yang pertama kali masuk adalah mendapatkan respon positif dari konsumen, sehingga langsung memaksimalkan pendapatan awal dari produk dan atau layanan yang ditawarkan kepada pelanggan.

3. Perusahaan dapat memperpanjang product life cycle dengan kemampuan bersaing yang baik jika memiliki nilai (Valuable), langka (Rare) dan tidak mudah ditiru (Imitability) oleh pesaing maupun pendatang baru, serta dikelola (Organized) dengan baik oleh manajemen sehingga mampu dipertahankan (Maulana, N. 2017). Perusahaan sudah mengantisipasi aksi pesaing sedari dini dan mampu beradaptasi terhadap perubahan pasar.

4. Perusahaan memperhatikan budaya setempat dalam perencanaan strategis terutama dalam menghadapi pesaing. Kekuatan pesaing yang sering terjadi adalah menduplikasi produk dan harga menjadi hal yang penting dipertimbangkan dengan cakupan target pasar yang tidak pasti. Dalam menghadapi ini strategi perintis cocok dengan strategi diferensiasi produk, harga dan promosi.

5. Ekspansi berupa penambahan outlet atau gerai perlu dilakukan untuk menunjukan kemampuan 
perusahaan yang semakin meningkat, namun tidak perlu ekspansi secara besar. Pertimbangan saat melakukan ekspansi dengan memperhatikan kemampuan setiap gerai untuk meningkatkan keuntungan setelah dikurangi biaya operasional, mempertahankan standarisasi pelayanan termasuk kemampuan kapasitas jalur distribusi serta daya beli konsumen.

6. Peraturan pemerintah memberikan pengaruh yang sangat besar terhadap model bisnis, kemampuan untuk mengembangkan usaha.

\section{KESIMPULAN}

Berdasarkan studi kasus product life cycle dari conviniene store, disimpulkan bahwa lamanya periode di pasar setiap produk perintis dan pemimpin pasar tergantung pada keberhasilan perintis dalam meningkatkan dan memperkuat posisi di pasar, merespon pengikut dan konsumen. Perusahaan telah mempersiapkan competitive advantage strategies untuk setiap produk yang diperkenalkan ke pasar, namun harus selalu diantisipasi dengan strategi yang berbeda di setiap tahap siklus produk terutama dalam menghadapi pesaing yang menduplikasi seluruh competitive adventage yang melekat di produk. Pengaruh eksternal dari perilaku sosial geografi konsumen turut menjadi perhatian selain teknologi dan promosi yang ditawarkan. Banyaknya gerai/outlet bukan menjadi strategi kompetisi yang prima, justru memberi kesempatan kepada pengikut pasar untuk melakukan duplikasi.

\section{DAFTAR PUSTAKA}

A. Pearce II, John., B. Robinson Jr, Richard. Strategic Management-Formulation, Implementation and Control. Tenth Edition.2007. United State.

E. Gomez, Jorge., R. Ramirez, Edgar. Electronic Business Journal. Volume 13, Issue 10, 2014. Is There a Real Pioneers Advantage Lesson Learned after almost Thirty Years: of Research.

Fadilah, J. Jurnal Komunikasi. Volume VII Nomor 2 September 2016. Consumer Insight Remaja Pada Seating Area Convenience Store 7Eleven.

Kalicanin, Dorde. A Question of Strategu of To be Pioneer or a Follower. Faculty of Economics,
University of Belgrade. DOI:10.2298/EKA 08177089k.

Kho, B. Produksi dan Operasional. Juni 2017. Pengertian Siklus Hidup Produk (Product Life Cycle)

Kotler, Philip. Manajemen Pemasaran-Analisis, Perencanaan, Implementasi dan Kontrol (Marketing Management 9e). 1997. Upper Saddle River, New Jersey 07458.

Kuntjoroadi, W, Safitri, N. Bisnis dan Birokrasi, Jurnal Ilmu Administrasi dan Organisasi. Volume 16. Nomor I. April 2009. Analisis Strategi Bersaing dalam Usaha Penerbangan Komersial.

Maulana, Noverina. Pesan manis dipahitnya Kisah Sevel Indonesia. Juli 2017. https://swa.co.id/swa/my-article/pesanmanis-di-pahitnya-kisah-sevel-indonesia

Mittal, S., Swami, S. Vikalpa. Volume 29. No 3. Juli-September 2004. What Factor Influence Pioneering Advantage of Companies?

Modern International Anual Report tahun 2011.

Modern International Anual Report tahun 2012.

Modern International Anual Report tahun 2015.

Modern International Anual Report tahun 2017.

P. Simbolon, F. Binus Business Review. Volume 3 Nomor 1. Mei 2012. 7-Eleven Melejit Lewat Lifestyle.

Praslina, L., Viksne, K., Cumakovs, A., Batraga, A. Economic Science for Rural Development. No.35, 2014. Innovative Competition Advantage Determination Model.

S. Day, George., J. Reibstein., E. Gunther, Robert. The Wharton School. Dynamic Competitive Strategy, 1997. United State.

Sukirno, S. Mikroekonomi Teori Pengantar Edisi Ketiga. 2016. Depok

W. Weiss, Joseph. Business Ethics-A Stakholder and Issues Management Approach.2006. Canada.

W. Gluck, Frederick., P. Kaufman., Stephen., S. Walleck, A. Juli 1980. Strategic Management for Competitive Advantage. Harvard Business Review. https://hbr.org/1980/07/strategicmanagement-for-competitive-advantage

Wulandari, Respati., Ronaldy Polla, J., Sriwardiningsih, Enggal. Jurnal Manajemen Indonesia, Volume 15 Nomor 3, Desember 2015. Strategi Marketing Entry Convinience Store di Indonesia.

http://www.businessdictionary.com/definition/follo wer-advantage.html 
https://www.jurnal.id/id/blog/2017-4-penyebabtutupnya-bisnis-7-eleven-di-indonesia/

https://www.pelajaran.co.id/2017/16/pengertianproduk-jenis-klasifikasi-dan-tingkatanproduk.html

https://etapps.indiatimes.com/fcm_webnotification. $\mathrm{cms}$ https://en.wikipedia.org/wiki/Product_(busin ess)

https://www.poshighway.com/blog/retailingconcept-4-principles-every-retailershould-know 